\title{
ON NON-AGRICULTURAL AND NON-TOURISM ECONOMIC INDUSTRIES IN RURAL AREAS
}

\author{
Vladan HRUŠKA ${ }^{1} \bullet$ Tomáš SIVIČEK ${ }^{2} \bullet$ Konrad CZAPIEWSKI ${ }^{3}$ \\ ${ }^{1}$ Jan Evangelista Purkyně University in Ústí nad Labem, Faculty of Science \\ Department of Geography, České mládeže 8, 400 96, Ústí nad Labem, Czechia \\ vladan.hruska@ujep.cz \\ 2Jan Evangelista Purkyně University in Ústí nad Labem, Faculty of Social and Economic Studies \\ Department of Economics, Moskevská 54, 40096 Ústí nad Labem, Czechia \\ tomas.sivicek@ujep.cz \\ ${ }^{3}$ Institute of Geography and Spatial Organization, Polish Academy of Sciences \\ Twarda 51/55, 00-818 Warsaw, Poland \\ konrad@twarda.pan.pl
}

\begin{abstract}
The aim of this article is to support another view of rural economies than one focused mainly on agriculture. The reason for such a view is the fact that the economic importance of other than agricultural economic activities (e.g. in manufacturing, services) in rural areas of developed countries is much larger than that of agriculture. Despite this new economic orientation of rural areas, rural developemt policies are still heavily focused on agriculture. To support these statements, a changing nature of rural economies of developed countries is discussed in contrast to the stagnating focus of rural studies and rural development policies.
\end{abstract}

Key-words: rural economy, rural studies, rural planning, entrepreneurship.

\section{Introduction}

For centuries agriculture was the dominant source of employment in rural areas and the driving force of rural economies. It had a pervasive influence on the organization of rural society and culture (Woods 2005). When rural development was spoken about, it traditionally meant taking measures in order to increase agricultural production. In the post-war period, the dominance of agriculture reached its limits. At the very beginning of this period one of the main policy goals was to provide food security (Burton 2004; Lapping 2006) which required the maximization of agricultural production.

Besides supranational authorities within the European Union responsible for the Common Agricultural Policy, national authorities also played an important role in this endeavour - they set the necessary legislative, financial and institutional background for this mode of agricultural production. Such support established a tight knit relationship 
between farmers and representatives of various national institutions which secured the growing volume of agricultural production (Murdoch 1992) and formalised rural space only as a source of food and timber in which farmers received a high level of authority.

Such organisation of agricultural production hit its target, agricultural output rose significantly and food security was reached in many agricultural products at national level. Nevertheless negative aspects of the productivist organisation of agriculture also occurred - overproduction and its very costly subsidizing, decreasing employment in agriculture (and hereby in rural areas as well) caused by rapid technological modernization of farms, soil degradation and other environmental problems. Therefore, since the 1980s in the United Kingdom (or 1990s in the context of the post-socialist countries including Visegrad countries) we can speak about the crisis in agriculture (Woods 2005) or the crisis of productivism (Lowe et al. 1993) and about the destruction of the tight-knit links between farmers and political representatives. Also on the European level the Common Agricultural Policy has faced strong criticism over the last decades due to its impact on the market in terms of generating surpluses while keeping prices above the global average and limiting access to the common market for competitors from developing countries. Therefore the reforms shifted the accent from quantity towards quality including the environmental protection aspects, and rural development (Bureau 2012; European Union 2010).

The retreat of agriculture did not appear in a vacuum, it was conditioned by wider social and economic processes which shape present rural localities. The massive subsidizing of agricultural production was not consistent with an increasingly pervasive influence of neo-liberalism on the ways of restructuring of the former welfare and socialist states. As a result, the volume of production subventions decreased rapidly and brought a destabilization of farms resulting in the laying off of farm workers and growing unemployment rates in rural areas. Farms in the post-socialist countries particularly faced big problems caused by limits on direct payments for new EU member states due to worries about cheap production (due to the low costs of production factors and the volume of output). Their competitive advantage was decreased by lower co-financing from the state budget in comparison to the EU-15 members. Moreover, the destabilization of farms in the post-socialist countries was also intensified by processes of privatization and restitution of land (especially in Czechia and Slovakia) and later by their integration into the highly competitive European and global market.

These substantial changes in farming have been accompanied by the transition from the industrial society to the information (post-industrial) society. The expansion of ICT technologies together with intensifying individual mobility based on growing car ownership have exposed rural areas to the process of counterurbanization which has conditioned an extensive inflow of service class inhabitants to rural areas. Class recomposition significantly increases the human and social capital of rural areas and weakens the power position of farmers (Murdoch and Marsden 1994). An influx of middle class residents has promoted the formation of new business start-ups in rural areas (Johnson and Rasker 1995; Kalantaridis 2010; Herslund 2012). Growing individual mobility has also caused the development of tourism and recreation, and together with the counterurbanization process has enabled the transformation of rural areas from a production area dominated by agriculture to an area of consumption where landscape, traditions, fresh air, tranquillity etc. are becoming commodities for sale (Woods 2011). The spatial deconcentration tendency could be demonstrated not only by individual mobility but also by the growing 
dispersion of industrial and commercial estates especially in the peri-urban zones (Sýkora 2003). This led to the industrialization of some rural localities, as the development of transport technologies and infrastructure diminished the obstacle of distance and decreased the cost of transporting material goods (Marini and Mooney 2006). The above mentioned processes of economic restructuring determined the development of both capitalist and former socialist countries, however in the context of the post-socialist countries it is necessary to stress that industrialization or more generally entrepreneurship in rural areas has been enabled by the renewal of private enterprise.

All the same, such economic restructuring has significantly changed the structure of rural economies within which agriculture is no more the dominating sector measured by its contribution for employment and national GDP (Atterton et al. 2012: 126) (for more evidence see article by Hruška and Czapiewski 2015).

\section{A reflection of changing rural economies in rural studies}

In spite of the decreasing importance of agriculture for the economy its symbolic importance still endures in local, national, European political and lay discourse as a legacy of the productivist period of agriculture. As Lapping (2006: 118) contends: "Over the past half-century or so the landscape and political economy of rural planning and policy demonstrate an amazing consistency and lack of imagination in terms of their focus and orientation. In many national and international contexts an emphasis on agriculture as rural persists".

Similarly Rowley (2003) in the same book draws our attention to the fact that in the US "policymakers continue to believe, or at least act as if they believe, that farming is the sum total of rural life. Therefore, policies aimed at supporting agriculture are touted as 'rural economic and community development' when in truth their effect on the larger economy and community is minimal. Yes they help, but most of the benefit goes to landowners (many of whom neither farm nor even live in the area) and many of the dollars head straight off the land, past the town, and out of the area, never to be seen again" (Rowley 2003, quoted in Lapping 2006: 118).

These statements demonstrate that agriculture is deeply embedded in existing national and supra-national planning documents. The Common Agriculture Policy (CAP) could serve as an example - despite many reforms, the current position of agriculture still remains very strong, when measured by the amount of money allocated for agriculture in the EU budget, which is around 40 per cent ${ }^{1}$, although it has dropped from more than 70 per cent (EU 2014). Gray (2000) contends that due to the CAP the perception of rural is still linked with agriculture which creates the encompassing concept defining the nature of present European rural areas. This could also be demonstrated on the approach to rural planning and development of Visegrad countries (see Kovács et al. 2015).

One of the reasons of agricultural dominance over other economic sectors could be its massive support generated by the academic discourse of rural development. This kind of discourse is formed mostly within rural studies, therefore it is necessary to discuss

${ }_{1}^{1}$ For the period of 2007-2013 for Preservation and Management of Natural Resources it was $42.31 \%$ and for the period of 2014-2020 for Sustainable growth: natural resources: it is $38.87 \%$ (both based on commitments in EUR million and 2011 prices). 
their development in this article. Rural studies could be considered as a set of approaches based on intersections of various scientific disciplines, more or less intensive, dealing with rural areas - geography, sociology, anthropology, agricultural economics, spatial planning and political science. However, the former three played the crucial role in the constitution of rural studies (Panelli 2006: 64). As the character of this volume is rather geographical, the development of rural studies will be discussed from a rural-geographical point of view.

The origins of rural geography could be traced back to the tradition of regional geography. Until the 1960s (Woods 2011) regional geographers focused on issues related to rural space (Cloke 1989), as they researched the relationship between human and nature under the influence of geographical (environmental) determinism or possibilism. Moreover, at that time agriculture, as one of the most important economic activities, attracted the attention of many geographers. In the post-WWII period, or rather from the 1960s scientific interest in rural space decreased significantly at the expense of booming urban areas. Similarly, rural geography also experienced a fallow period whereas considerable theoretical and methodological progress was made in urban geography (Cloke 1985).

Nevertheless, rural areas did not disappear completely from the scientific horizon, rather, they became a part of agriculture whose power position increased due to the post-WWII endeavour to ensure food security of the recovering national economies. The demand for modernization and industrialization of agriculture caused the growth in the popularity of geography of agriculture until the end of the 1970s (Cloke 1985). At that time, non-agricultural geographical contributions appeared very rarely (Woods 2009) and at the end of the 1970s the crisis of rural geography culminated, partly as a result of its low political and social relevance and insufficient focus on real rural problems. Its concept was largely limited to presenting demographic and economic topics, and some techniques in planning and management of rural areas. This was the period in which the influence of the division of human geography into subfields was most conspicuous. Until the mid-1980s, geographical problems related to rural development were presented from a functionalist perspective, while social and geographical transformations were tackled in the context of urbanization (social, economic, tourism etc.). Research methodology was driven primarily by quantitative methods and the presentation of spatial structure in different processes (see Pacione 1984; Phillips and Williams 1984).

The 1970s and 1980s brought substantial changes to rural areas of the United Kingdom and other developed countries. Growing in-migration of a service class to rural areas, the crisis of productivism, growing regional (social and economic) disparities - these and other processes challenged geographers and demanded more critical rural research which would also include issues other than agriculture. New approaches to and direction in research were needed in order to interpret the changes taking place across national economies through the use of social science methodologies, particularly sociology.

Textbooks from the 1980s offer a more well-rounded and diverse set of topics, which is mainly a reflection of the expansion of rural functions, e.g. the development of residential, tourism, recreational, service, and landscape protection functions, and consequently a greater interest in the conditions and quality of life, as well as local politics, on the part of rural geography (see Woods 2005). These topics have become increasingly penetrated by political-economic approaches which have helped to change the perception of rural areas especially in terms of critical evaluation of rural idyll and their definition derived from the urban-rural dichotomy. Further substantial progress in rural studies has been 
made since the introduction of post-modern approaches at the end of the 1980s which marked their opening for concepts like identity, representation, discourse, power, others etc. (Woods 2005). As a result, current textbooks incorporate not only an expanded list of rural geography topics but also cultural topics. Changes are also visible in the differing interpretations of certain processes within the framework of a new research model (critical currents) (Czapiewski and Wójcik 2014). Political-economic and post-modern approaches markedly reinforced the position of rural geography among other geographical sub-disciplines so that Cloke (1997) believes that at the end of the millennium rural studies experienced their most exciting period. Similarly Evans (2008) believes that rural geography is one of the most dynamic sub-disciplines of geography.

For sure the range of issues researched at the present time within rural studies is much broader in comparison to the situation at the end of the 1960s. However, in the authors' opinion, there still remains some room for criticism. One of them, which the central idea of this volume represents, is the very limited focus of rural studies on non-agricultural and non-tourism economic sectors. Let us demonstrate this in the following analysis of the latest research papers from two leading rural journals - Journal of Rural Studies (volumes 28-36 = 233 papers) and Sociologia Ruralis (volumes 46-54 = 207 papers). Within these journals all 440 papers (focused both on economic and non-economic issues) were examined of which:

- 231 focus on diverse aspects of rural economies from which,

- 188 focus on agriculture,

- 29 focus on other economic activities (mostly forestry, fishing, tourism),

- 14 focus on the economy in general (Hruška 2014).

It is perfectly obvious, that the agricultural focus of both journals is still dominant (81.4 per cent of papers focus on agriculture - Fig. 1). However, does the composition of economically-focused papers really reflect the economic situation of rural areas? If the importance of agriculture for rural employment in developed countries is considered (for example employment in agriculture accounted for about 9 per cent in predominantly rural regions of 20 OECD countries in 2000; OECD 2010), we are afraid that it is not possible to answer this question with a "yes".

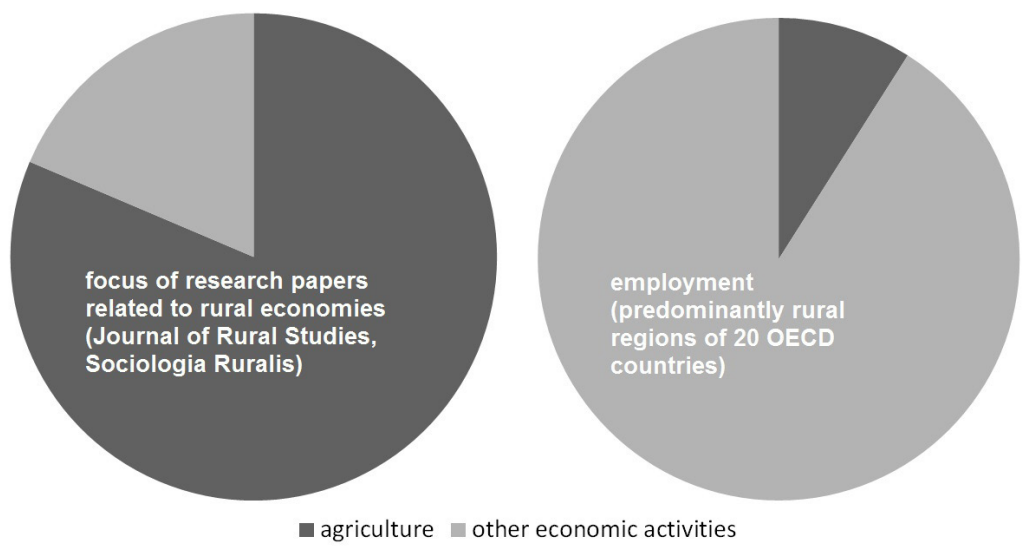

Fig. 1. The disproportion between rural-economic research and rural employment? Source: Hruška (2014). 
This is not to reject the central role of agriculture in the production of food and raw material, the shaping of the rural landscape in OECD countries (in 2005 it accounted for 37 per cent of total land use and 68 per cent if we include land for forests; OECD 2010) and the management of natural resources, environment and landscape (Atterton et al. 2012: 126). Also its importance in the construction of rural identities is not negligible. However, if one of the main goals of rural development is stabilizing the rural population, the authors are afraid that the promotion of agriculture is not the best way to achieve this target.

Instead, the authors call for efficient job-generating rural development policies based on economic activities other than agricultural (for more recommendations see Hruška, Czapiewski and Kovács 2015). A lack of jobs is usually considered to be the main or one of the main driving forces of depopulation of peripheral rural areas. Therefore a key part of rural regeneration should be 'the fostering of a culture in which entrepreneurship is valued and flourishes' (Moseley 2003: 60). However, on this point caution is needed as extending the job offer in rural space may not necessarily be the main goal of all rural localities. In peripheral rural areas new investments might be kindly welcomed since unemployment represents a big problem there, whereas in suburban or environmentally attractive localities such measures might not be incorporated into development policies due to the relatively high accessibility of jobs in urban areas and the opposition of local people who require a peaceful and idyllic landscape. Consequently, in such an idyllic representation of rural areas new manufacturing premises simply do not fit in.

When we return to the demand for job-generating policies or policies promoting entrepreneurship in other than agricultural economic sectors, let us demonstrate this using the example of the Moravian-Silesian Region in the Czech Republic (its rural part consists of municipalities with a population below 3,000). In 2011 (based on the calculation derived from the Census 2011), there were more than 83,000 jobs in rural areas of which only 5.7 per cent were in agriculture, forestry and fishing and 34.2 per cent in manufacturing. In circumstances like these there is a high probability that each unit invested in manufacturing could generate more jobs than the same financial amount invested in agriculture.

\section{Entrepreneurship in rural areas}

The economic theory has also accepted the influence of other factors of production apart from land including technical development or entrepreneurship since the labour theory of value was a prevailing stream of economic thinking. Adam Smith, David Ricardo and Karl Marx elaborated on different aspects of factor endowment and their substitution in the production process. Nowadays, under conditions of globalisation, characterised by the vivid interconnection of the flow of goods, services, labour and capital, the ownership of traditional production factors is no more a limitation or precondition for success and economic growth. This may also be applicable for rural development. Although agriculture will most likely remain one of the pillars of rural development, there are other opportunities less dependent on agricultural activity and its output. 
At the European level, this is reflected for example, in the European Employment Strategy ${ }^{2}$ from 1997. The EU took into consideration the broader context of rural development policies since rural regions lagged behind urban areas in terms of economic growth and job creation. And it was accompanied with slower development of the tertiary sector and human capital as well as with a small diversification into non-agricultural activities. This was also strengthened by low support from the EU. The Communication of the EC suggests a multi-sectoral approach, local partnerships, and further development of skills to improve adaptability and job creation (European Commission 2006). Following the previous Lisbon strategy, the current period of 2014-2020 will focus on fulfilling the strategy for Europe 2020.

Both at European and national level, there is a significant shift from supporting solely small and medium enterprises (SMEs), although they still remain important objects of interest, to the crosscutting and more complex entrepreneurship policies (Xheneti and Smallbone 2008). Therefore, it is very frequently a part of regional policy and regional innovation policies (Gineite and Vilcina 2011; Cooke 2011; Blažek et al. 2013). In an effort for inclusive growth, social entrepreneurship and social economy represent plenty of new interesting opportunities applicable also in rural areas, which do not have developed research and development infrastructure at their disposal (Lepoutre et al. 2013; European Commission 2010; Lan et al. 2014).

Besides institutional barriers including insufficient or incoherent strategies and policies aimed at the support and development of entrepreneurship, which negatively influence the aspiration of people to start their own business, there is another specific element visible in post-communist countries. It is the low ambition of people for starting a new business which hinders the development of regional and rural economies. This could be partly related to negative experiences with the transformation and privatisation, but could also be connected with a fear of failure and with perceived insufficient financial support (Hlaváček et al. 2015) (for detailed analysis of entrepreneursip in Visegrad countries see Cerić 2015). Based on empirical evidence, it is desirable that governments focus more on the promotion of "prosperity pull" entrepreneurship related to the discovery of new opportunities instead of "recession push" entrepreneurship related to necessity in the mid- and long run (Bruenjes and Diez 2013). However, as Kibler (2013) suggests, regional aspects such as educational backgrounds, income levels, population density, economic structure etc. influence decisions about starting a business. Rural entrepreneurship might also be described as place-dependent potential able to contribute to economic growth and local development, but it still might be influenced by exogenous determinants. Thus, the combination of stimulating local initiatives with a sectoral approach might be effective (Baumgartner et al. 2013).

However, research of Chromý et al. (2011) revealed a problem in the entrepreneurial thinking of representatives of Czech rural municipalities who are very sceptical about doing business in rural areas. In the questionnaire survey with representatives of 1,074 rural municipalities (defined as municipalities with a population below 3,000) the perception of their municipalities was examined. According to the rural representatives, rural municipalities are not suitable places for the fulfilment of capable people or doing business. More-

\footnotetext{
2 The overview is not exhausting and there are further related and relevant documents of the European Union, like Council Regulation (EC) No. 1698/2005 or Council Decision 2006/144/EC or Communication from the Commission $\operatorname{COM}(2010) 672$ final.
} 
over, despite the shrinking population of many rural municipalities they do not perceive the creation of new jobs as an important issue in their development endeavour (Chromý et al. 2011). These statements may seriously threaten conditions for new business start-ups in rural areas as rural mayors could shape local conditions for doing business (Fig. 2).
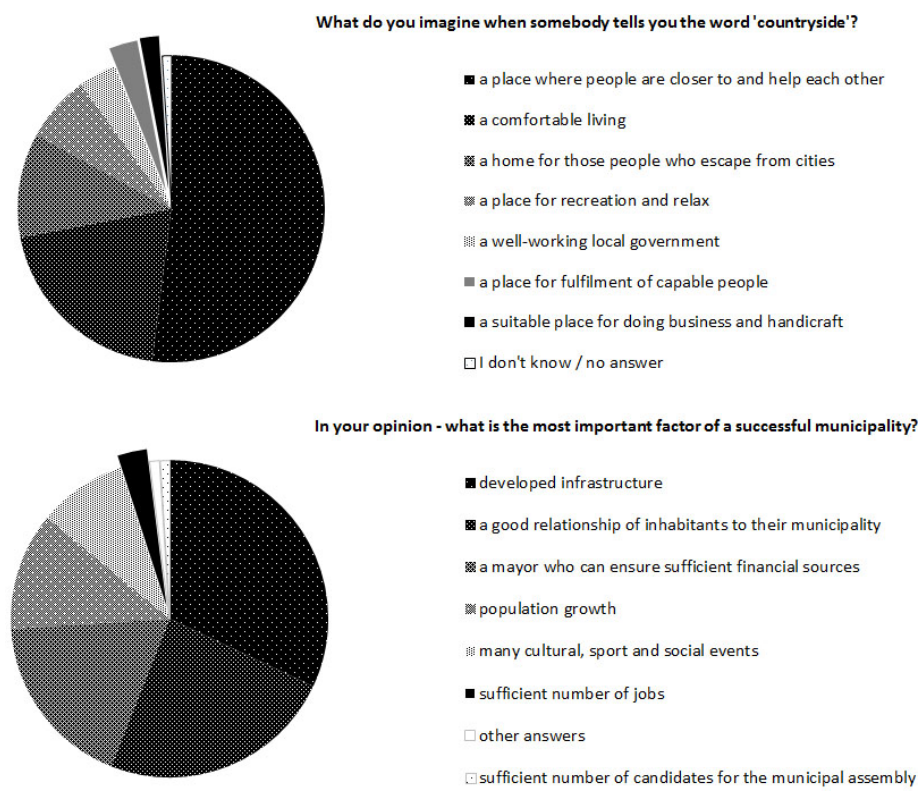

Fig. 2. Opinions of the representatives of Czech rural municipalities Source: Chromý et al. (2011).

\section{Conclusions}

Concluding, it is necessary to stress that in the present post-modern, highly mobile and fluid era rural areas could also benefit from, or participate in economic development. As the best practices from Egedy et al. (2015) show, despite the limitations of rural milieu (see Novotný et al. 2015) rural areas can offer suitable conditions for starting, developing and expanding new or already established businesses. Distance from main markets, at least in the context of Visegrad countries, is no longer the decisive element which defines the economic success of a particular rural locality. According to Young (2006) distance, as a territorial separation of actors, consists of three dimensions: natural or physical attributes, technological infrastructure and social relationships. As such it could be shaped or rather, is performed by a broad range of actors and it is just this performance of distance which is a key factor causing inequalities in rural economies and the performance of rural firms. Therefore it depends on the agency of actors (for example rural entrepreneurs) and their ability to configure social and technological systems that form rural connectivity (Young 2006), whereas the importance of natural or physical attributes is decreasing. 


\section{References}

Atterton J., Bryden J., Johnson T., 2012, Rural economic transformations in the UK and US, [in:] Shucksmith M. et al., Rural transformations and rural policies in the US and UK, Routledge, London, pp. 117-137.

Baumgartner D., Schulz T., Seidl I., 2013, Quantifying Entrepreneurship and Its Impact on Local Economic Performance: A Spatial Assessment in Rural Switzerland, Entrepreneurship and Regional Development, 25, pp. 222-250.

Blažek J. et al., 2013, Emerging Regional Innovation Strategies in Central Europe: Institutions and Regional Leadership in Generating Strategic Outcomes, European Urban and Regional Studies, 20, pp. 275-294.

Bruenjes J., Diez J. R., 2013, 'Recession Push' and 'Prosperity Pull': Entrepreneurship in a Rural Developing Context, Entrepreneurship And Regional Development, 25, pp. 251-271.

Bureau J., 2012, Where Is the Common Agricultural Policy Heading?, Intereconomics/Review Of European Economic Policy, 47, pp. 316-321.

Burton R., 2004, Seeing through the 'good farmer's' eyes: towards developing an understanding of the social symbolic value of 'productivist' behaviour, Sociologia Ruralis, 44, pp. 195-215.

Cerić D., 2015, Macro-regional empirical analysis of the economic climate in Visegrad countries, Studia Obszarów Wiejskich, 39, pp. 49-58.

Chromý P., Jančák V., Marada M., Havlíček T., 2011, Venkov - žitý prostor: regionální diferenciace percepce venkova predstaviteli venkovských obcí v Česku, Geografie, 116, pp. 23-45.

Cloke P., 1985, Whither Rural Studies?, Journal of Rural Studies, 1, pp. 1-9.

Cloke P., 1989, Rural geography and political economy, [in:] Peet R., Thrift N., New models of geography: the political economy perspective, Routledge, London, pp. 164-197.

Cloke P., 1997, Country backwater to virtual village? Rural studies and 'the cultural turn', Journal of Rural Studies, 13, pp. 367-375.

Cooke P. et al., 2011, Handbook of Regional Innovation and Growth, Cheltenham, Edward Elgar Publishing.

Czapiewski K., Wójcik M., 2014, Towards a post-structuralist and cultural turn in researching rurality in Poland: a geographical perspective, [in:] Kasabov E. (ed), Rural cooperation in Europe. In search of the 'relational rurals', Palgrave Macmillan, Houndmills, pp. 231-265.

Egedy T., Cerić D., Konopski M., Kučerová S., Kulla M., Nestorová-Dická J., Svobodová R., 2015, Entrepreneurship as a potential driving force for the further development of rural areas-good examples from Visegrad countries, Studia Obszarów Wiejskich, 39, pp. 103-128.

European Commision, 2006, Communication from the Commission to the Council and the European - Parliament Employment in rural areas: closing the jobs gap, Brussels. [cit. 2015-02-14]: URL: http://eur-lex.europa.eu/legal-content/EN/TXT/?uri=celex:52006DC0857

European Commision, 2010, Communication from the Commission. Europe 2020. A strategy for smart, sustainable and inclusive growth, Brussels. [cit. 2015-02-21]: URL: http://eur-lex.europa. eu/LexUriServ/LexUriServ.do?uri=COM:2010:2020:FIN:EN:PDF

European Commision, 2014, Budget, Brussels. [cit. 2014-02-05]: URL: http://ec.europa.eu/budget European Union, 2010, Consolidated versions of The Treaty on the European Union and The Treaty on the Functioning of the European Union, Charter of Fundamental Rights of the European Union, Luxembourg, Publications Office of the European Union.

Evans N., 2008, Rural Geography: Processes, Responses and Experiences in Rural Restructuring (Book Review), Global Built Environment Review, 6, pp. 63-65. 
Gineite M., Vilcina A., 2011, Development of Entrepreneurship as a component of regional policy in Latvia, European Integration Studies, 5, pp. 186-191.

Gray J., 2000, The Common Agricultural Policy and the re-invention of the rural in the European Community, Sociologia Ruralis, 40, pp. 30-52.

Herslund L., 2012, The rural creative class: counterurbanisation and entrepreneurship in the Danish countryside, Sociologia Ruralis, 52, pp. 235-255.

Hlaváček P., Žambochová M., Siviček T., 2015, The Influence of the Institutions on Entrepreneurship Development: Public Support and Perception of Entrepreneurship Development in the Czech Republic, Amfiteatru Economic, 17, pp. 408-421.

Hruška V., 2014, Neglected Rural Economic Industries: Revealing Gaps in Rural Research, Paper presented at IGU Regional Conference, Kraków.

Hruška V., Czapiewski K., 2015, Changing rural economies: theoretical background and empirical evidence, Studia Obszarów Wiejskich, 39, pp. 59-76.

Hruška V., Czapiewski K., Kovács Z., 2015, Rural economic development in the post-agricultural era: policy recommendations, Studia Obszarów Wiejskich, 39, pp. 129-144.

Johnson J., Rasker R., 1995, The role of economic and quality of life values in rural business location, Journal of Rural Studies, 11, pp. 405-416.

Kalantaridis C., 2010, In-migration, entrepreneurship and rural-urban interdependencies: The case of East Cleveland, North East England, Journal of Rural Studies, 26, pp. 418-427.

Kibler E., 2013, Formation of Entrepreneurial Intentions in a Regional Context, Entrepreneurship and Regional Development, 25, pp. 293-323.

Kovács Z., Csachová S., Ferenc M., Hruška V., Konopski M., 2015, Development policies on rural peripheral areas in Visegrad countries: a comparative policy analysis, Studia Obszarów Wiejskich, 39, pp. 77-102.

Lapping M., 2006, Rural policy and planning, [in:] Cloke P., Marsden T., Mooney P. (eds.), Handbook of rural studies, SAGE, London, pp. 104-122.

Lan H., Zhu Y., Ness D., Xing K., Schneider K., 2014, The Role and Characteristics of Social Entrepreneurs in Contemporary Rural Cooperative Development in China: Case Studies of Rural Social Entrepreneurship, Asia Pacific Business Review, 20, pp. 379-400.

Lepoutre J., Justo R., Terjesen S., Bosma N., 2013, Designing a global standardized methodology for measuring social entrepreneurship activity: the Global Entrepreneurship Monitor social entrepreneurship study, Small Business Economics. [cit. 2014-11-22]: URL: http://link.springer. com/article/10.1007/s11187-011-9398-4\#page-1>

Lowe P., Murdoch J., Marsden T., Munton R., Flynn A., 1993, Regulating the new rural spaces: the uneven development of land, Journal of Rural Studies, 9, pp. 205-222.

Moseley M. J., 2003, Rural Development: Principles and Practice, SAGE, London.

Murdoch J., 1992, Representing the region: Welsh farmers and the British state, [in:] Marsden T., Lowe P., Whatmore, S. (eds), Labour and Locality: uneven development in the labour process, London, David Fulton, pp. 160-181.

Murdoch J., Marsden T., 1994, Reconstituting rurality: class, community and power in the development process, UCL Press, London.

Marini M., Mooney P., 2006, Rural economies, [in:] Cloke P., Marsden T., Mooney P. (eds.), Handbook of rural studies, SAGE, London, pp. 91-103.

Novotný L., Hruška V., Egedy T., Mazur M., 2015, Defining rural areas of Visegrad countries, Studia Obszarów Wiejskich, 39, pp. 21-34. 
OECD, 2010, Agricultural Policies and Rural Development: a Synthesis of Recent OECD Work. [cit. 2015-04-21]: URL: http://www.oecd.org/agriculture/44561502.pdf

Pacione M., 1984, Rural Geography, Harper and Row, London.

Panelli R., 2006, Rural Society, [in:] Cloke P., Marsden T., Mooney P. (eds.), Handbook of rural studies, SAGE, London, pp. 63-90.

Phillips D., Williams A., 1984, Rural Britain. A Social Geography, Basil Blackwell, Oxford.

Rowley T., 2003, The rural identity crisis. [cit. 2013-01-08]: URL: www.rupri.org

Sýkora L., 2003, Suburbanizace a její společenské důsledky, Sociologický časopis, 39, pp. 55-71.

Woods M., 2005, Rural Geography: Processes, responses and experiences in rural restructuring, SAGE, London.

Woods M., 2009, Rural geography, [in:] Kitchin R., Thrift N. (eds.), International encyclopedia of human geography, Elsevier, Amsterdam, pp. 429-441.

Woods M., 2011, Rural, Routledge, London.

Xheneti M., Smallbone D., 2008, The Role of Public Policy in Entrepreneurship Development in Post-Socialist Countries: A Comparison of Albania and Estonia, EBS Review, 24, pp. 23-36.

Young N., 2006, Distance as a hybrid actor in rural economies, Journal of Rural Studies, 22, pp. 253-266. 
http://rcin.org.pl 